\title{
Inhibition of Caspases Prevents Ototoxic and Ongoing Hair Cell Death
}

\author{
Jonathan I. Matsui,, ${ }^{1,2}$ Judith M. Ogilvie, ${ }^{1,3}$ and Mark E. Warchol, ${ }^{1,2,4,5}$ \\ ${ }^{1}$ Central Institute for the Deaf, Fay and Carl Simons Center for Biology of Hearing and Deafness, ${ }^{2}$ Division of Biology and \\ Biomedical Sciences, Neuroscience Graduate Program, and Departments of ${ }^{3}$ Ophthalmology and Visual Sciences, \\ ${ }^{4}$ Otolaryngology, and ${ }^{5}$ Anatomy and Neurobiology, Washington University School of Medicine, St. Louis, Missouri 63110
}

\begin{abstract}
Sensory hair cells die after acoustic trauma or ototoxic insults, but the signal transduction pathways that mediate hair cell death are not known. Here we identify several important signaling events that regulate the death of vestibular hair cells. Chick utricles were cultured in media supplemented with the ototoxic antibiotic neomycin and selected pharmacological agents that influence signaling molecules in cell death pathways. Hair cells that were treated with neomycin exhibited classically defined apoptotic morphologies such as condensed nuclei and fragmented DNA. Inhibition of protein synthesis (via treatment with cycloheximide) increased hair cell survival after treatment with neomycin, suggesting that hair cell death requires de novo protein synthesis. Finally, the inhibition of caspases promoted hair cell survival after neomycin treatment.
\end{abstract}

Sensory hair cells in avian vestibular organs also undergo continual cell death and replacement throughout mature life. It is unclear whether the loss of hair cells stimulates the proliferation of supporting cells or whether the production of new cells triggers the death of hair cells. We examined the effects of caspase inhibition on spontaneous hair cell death in the chick utricle. Caspase inhibitors reduced the amount of ongoing hair cell death and ongoing supporting cell proliferation in a dosedependent manner. In isolated sensory epithelia, however, caspase inhibitors did not affect supporting cell proliferation directly. Our data indicate that ongoing hair cell death stimulates supporting cell proliferation in the mature utricle.

Key words: auditory; hair cell; vestibular; tissue culture; apoptosis; proliferation; caspase inhibitors; regeneration
The sensory hair cells of the inner ear detect sound and head movements. In mammals, hair cells can be lost through disease, aging, infection, or exposure to noise or ototoxic drugs, leading to permanent balance and/or auditory deficits. Morphological evidence from many vertebrate species suggests that the loss of hair cells occurs via programmed cell death (PCD; Jørgensen, 1981, 1991; Forge, 1985; Li et al., 1995; Forge and Li, 2000). Consistent with these observations, in situ terminal deoxynucleotidyl transferase-mediated biotinylated UTP nick end labeling of fragmented DNA (TUNEL labeling) identifies apoptotic hair cells in chicks (Kil et al., 1997; Nakagawa et al., 1997c; Torchinsky et al., 1999), rodents (Lang and Liu, 1997; Nakagawa et al., 1997a,b, 1998a,b,c; Usami et al., 1997; Zheng and Gao, 1997; Nishizaki et al., 1998; Zheng et al., 1998, 1999; Forge and Li, 2000; Pirvola et al., 2000), and humans (Jokay et al., 1998), suggesting that hair cell death occurs, at least in part, by PCD.

Programmed cell death via apoptosis occurs via an orderly series of cellular events (Raff, 1998), and some forms of PCD require new RNA and protein synthesis (Martin et al., 1988). Once PCD is initiated, a cascade of intracellular events culmi-

\footnotetext{
Received Oct. 4, 2001; revised Nov. 20, 2001; accepted Nov. 28, 2001.

This work was supported by the Division of Biology and Biomedical Sciences and the National Organization for Hearing Research Foundation (J.I.M.), by the Foundation Fighting Blindness (J.M.O.), and by National Institutes of Health Grant DC03576 and National Aeronautics and Space Administration Grant NAG2-1364 (M.E.W.). We thank Jaclynn Lett for her excellent histological and photographic assistance and Dr. Miriam Burton for help with fluorescent microscopy. We also thank Drs. Anne Hennig, Kenneth Lee, and Eugene Johnson Jr for their helpful discussions. Finally, we thank Karla Marz, David Fashena, and Drs. Edwin Rubel and Eugene Johnson Jr for their critical review of this manuscript.

Correspondence should be addressed to Mark E. Warchol or Jonathan I. Matsui, Central Institute for the Deaf, 4560 Clayton Avenue, St. Louis, MO 63110-1549. E-mail: mwarchol@cid.wustl.edu or jmatsui@cid.wustl.edu.

Copyright (C) 2002 Society for Neuroscience $\quad 0270-6474 / 02 / 221218-10 \$ 15.00 / 0$
}

nates in the activation of caspases, triggering a proteolytic cascade that leads to the degradation of the nuclear proteins of the cell (Salvesen and Dixit, 1997). Caspase inhibitors prevent PCD in many types of neurons (Salvesen and Dixit, 1997) and in auditory and vestibular hair cells (Liu et al., 1998; Forge and Li, 2000).

In the present study, chick utricles were cultured in media supplemented with selected pharmacological agents that influence signaling in identified cell death pathways. We determined that both cycloheximide and caspase inhibitors promoted hair cell survival after aminoglycoside exposure. Also, the mature avian vestibular sensory epithelia exhibit a low, ongoing level of cell proliferation (Jørgensen and Mathiesen, 1988; Roberson et al., 1992; Warchol and Corwin, 1993; Kil et al., 1997; Wilkins et al., 1999), which is accompanied by a comparable rate of spontaneous hair cell death (Kil et al., 1997; Wilkins et al., 1999). It is not known, however, whether the loss of hair cells stimulates supporting cell proliferation or whether proliferation triggers the apoptotic cell death of hair cells. Results indicate that ongoing hair cell death is causally related to ongoing supporting cell proliferation.

A preliminary report of portions of these data was presented previously (Matsui et al., 2000b).

\section{MATERIALS AND METHODS}

\section{Animals}

White Leghorn chickens (Gallus domesticus) were obtained from Truslow Farms (Chestertown, MD) or Charles River SPAFAS (Charles River, $\mathrm{CT}$ ) and were housed in the animal care facility of the Central Institute for the Deaf. All experimental protocols were approved by the Central Institute for the Deaf and the Washington University Institutional Ani- 
mal Care and Use Committee and conform to the Society for Neuroscience animal use guidelines.

\section{Culture techniques}

Organ cultures. Chicks (7-21 d posthatch) were killed with $\mathrm{CO}_{2}$ and decapitated. The lower jaw and the skin covering the head were removed, and the heads were immersed in $70 \%$ ethanol to kill surface pathogens. The remaining dissection was performed in a laminar flow tissue culture hood. The utricles were removed and transferred to chilled Medium 199 containing Hank's salts and HEPES buffer (Invitrogen, San Diego, CA). The otoconia were removed, and the utricles were cultured as organotypic explants in 48-well tissue culture plates (Costar, Cambridge, MA). Each well contained $200 \mu \mathrm{l}$ of culture medium, which consisted of Medium 199 supplemented with Earle's salts, $2200 \mathrm{mg} / 1$ sodium bicarbonate, $0.69 \mathrm{~mm}$ L-glutamine, $25 \mathrm{~mm}$ HEPES, and $10 \%$ fetal bovine serum (FBS; Invitrogen). Explants were incubated at $37^{\circ} \mathrm{C}$ in a humidified $5 \% \mathrm{CO}_{2} / 95 \%$ air environment for $1 \mathrm{~d}$ in vitro (1 DIV) to allow the utricles to adjust to the culture environment.

Pharmacological treatment of cultures. At the beginning of the second day in vitro, neomycin sulfate (Sigma, St. Louis, MO) was added to the culture medium for a final dilution of $0.2,0.5$, or $1 \mathrm{~mm}$. Cultures containing aminoglycoside-free medium were maintained in parallel and served as controls.

To determine whether protein synthesis was necessary for aminoglycoside-induced hair cell death, we cultured the utricles for $24 \mathrm{hr}$ with $1 \mathrm{~mm}$ neomycin and $1 \mu \mathrm{g} / \mathrm{ml}$ cycloheximide (Sigma). In experiments that examined caspase inhibition, Boc-Asp(Ome)-fluoromethyl ketone (BAF; Enzyme Systems Products, Livermore, CA) or z-Val-AlaAsp(Ome)-fluoromethyl ketone (zVAD; Enzyme Systems Products) was added to the medium for a final concentration of 10,50 , or $100 \mu \mathrm{M}$ for $\mathrm{BAF}$ or $25 \mu \mathrm{M}$ for zVAD. Cycloheximide and the caspase inhibitors were added to the cultures simultaneously with neomycin. Control cultures also received $0.1 \%$ dimethyl sulfoxide (DMSO). To examine the effects of cell cycle inhibition on ongoing cell death and supporting cell proliferation, we added $25 \mu \mathrm{M}$ aphidicolin (Calbiochem, San Diego, CA) to the culture medium.

To determine whether certain pharmacological agents had deleterious effects on hair cells, we cultured the utricles for $48 \mathrm{hr}$ with neomycin and putative cell death inhibitors (e.g., BAF), but without neomycin. Additional experiments examined the acute effects of caspase inhibitors on long-term survival of hair cells. After a $1 \mathrm{~d}$ treatment with neomycin and $50 \mu \mathrm{M}$ BAF the utricles were rinsed three times and maintained in Medium 199 and 10\% FBS for an additional $5 \mathrm{~d}$ (total time, 7 DIV). One-half of the culture medium was changed every other day.

Sensory epithelial cultures. To assess the direct effects of pharmacological agents on supporting cell proliferation, we isolated sensory epithelia from chick utricles as described previously (Warchol, 1995, 1999). Utricles were removed from chicks and placed in sterile Medium 199; the otoconia were removed. Then the utricles were incubated in thermolysin $\left(500 \mu \mathrm{g} / \mathrm{ml}\right.$ in Medium 199 with Earle's salts; Sigma) for $1 \mathrm{hr}$ at $37^{\circ} \mathrm{C}$ in a humidified $5 \% \mathrm{CO}_{2} / 95 \%$ air environment incubator and then returned to chilled Medium 199 for further dissection. A 27-gauge needle was used to dissociate the sensory epithelia from the basement membrane and associated connective tissue. Isolated sheets of sensory epithelia were transferred into fibronectin-coated culture wells (MatTek, Ashland, MA) containing $50 \mu \mathrm{l}$ of Medium 199 and 10\% FBS and incubated for $3 \mathrm{~d}$ to allow the sensory epithelium to adhere to the fibronectin substrate. Then the explants were maintained in $50 \mu \mathrm{l}$ of Medium 199 and $10 \%$ FBS in the presence of $0.1 \%$ DMSO, $50 \mu \mathrm{M}$ BAF, or $25 \mu \mathrm{M} \mathrm{zVAD}$ for an additional $2 \mathrm{~d}$ (total, $5 \mathrm{DIV}$ ). One-half of the medium was changed every other day.

\section{Tissue processing}

Cultured utricles and sensory epithelia explants were fixed with $4 \%$ paraformaldehyde for $20 \mathrm{~min}$ and then were rinsed with PBS unless otherwise stated. Also, immunohistochemical steps were performed at room temperature with thorough PBS washes between them, unless otherwise stated.

Primary antibodies. Mouse monoclonal anti-BrdU antibody was obtained from Becton Dickinson (San Jose, CA). Dr. J. H. Rogers (University of Cambridge, UK) generously donated the rabbit monoclonal anti-calretinin. Additional rabbit polyclonal anti-calretinin was obtained from Chemicon (Temecula, CA).

Fluorescent nucleic acid staining. Fixed utricles were immersed in bisbenzimide (Hoechst 33258; $20 \mu \mathrm{g} / \mathrm{ml}$; Sigma) in the dark for $1 \mathrm{hr}$.
Specimens were washed thoroughly with PBS and mounted on glass slides in glycerol/PBS (9:1).

TUNEL labeling. The ApopTag kit (Intergen, Purchase, NY) was used to label dying hair cells, following the protocol described by Kil et al. (1997). Fixed utricles were incubated in $90 \%$ methanol with $0.5 \%$ hydrogen peroxide $\left(\mathrm{H}_{2} \mathrm{O}_{2}\right)$ for $15 \mathrm{~min}$ and immersed in a blocking solution consisting of $5 \%$ nonfat dairy dry milk and $2 \%$ bovine serum albumin (BSA; Sigma) for $20 \mathrm{~min}$; this was followed by $1 \times$ equilibrium buffer for $10 \mathrm{~min}$. Then the tissue was incubated in TdT enzyme in a humidified oven for $30 \mathrm{~min}$ at $37^{\circ} \mathrm{C}$. A stop/wash buffer was added to the wells, and the tissue was incubated in the humidified oven for $30 \mathrm{~min}$. The specimens were exposed to digoxigenin for $30 \mathrm{~min}$ and then were reacted with $0.5 \mathrm{mg} / \mathrm{ml}$ diaminobenzidine (DAB) in $0.05 \mathrm{M}$ Tris buffer and $0.03 \%$ $\mathrm{H}_{2} \mathrm{O}_{2} / \mathrm{NiCl}_{2}$ for $5 \mathrm{~min}$. Utricles were mounted onto slides as whole mounts in glycerol/PBS.

Calretinin labeling. To assess the extent of hair cell survival quantitatively, we identified hair cells by using an antibody for calretinin (see Fig. 1) (Rogers, 1989). Fixed utricles were incubated in $90 \%$ methanol with $0.03 \% \mathrm{H}_{2} \mathrm{O}_{2}$ for $20 \mathrm{~min}$, followed by incubation in a blocking solution consisting of PBS, $2 \%$ normal horse serum (NHS; Sigma), $1 \%$ BSA, and $0.2 \%$ Triton X-100 for $20 \mathrm{~min}$. Then the tissue was placed immediately into a rabbit anti-calretinin primary antibody (1:2000; in PBS and 2\% NHS) and incubated overnight at $4^{\circ} \mathrm{C}$. Utricles were incubated in biotinylated goat anti-rabbit IgG antibody (1:150; in PBS and $0.1 \%$ NHS; Vector Laboratories, Burlingame, CA) for $2 \mathrm{hr}$, followed by avidinbiotin-horseradish peroxidase complex (Vector Laboratories) for $90 \mathrm{~min}$. Specimens were reacted with DAB for 5 min and mounted on microscope slides in glycerol/PBS.

Bromodeoxyuridine immunohistochemistry. To assay supporting cell proliferation, we added the mitotic tracer bromodeoxyuridine (BrdU; 3 $\mu \mathrm{g} / \mathrm{ml}$; Sigma) to cultures for the last $4 \mathrm{hr}$ in vitro. Specimens were processed for BrdU immunohistochemistry by following a standard protocol (Warchol and Corwin, 1996). Fixed utricles were incubated in $90 \%$ methanol with $0.03 \% \mathrm{H}_{2} \mathrm{O}_{2}$ for $20 \mathrm{~min}, 2 \mathrm{~N} \mathrm{HCl}$ for $30 \mathrm{~min}$, and blocking solution (PBS, 2\% NHS, 1\% BSA, 0.2\% Triton X-100) for $20 \mathrm{~min}$; then they were incubated overnight in mouse anti-BrdU monoclonal antibody (1:50; in PBS, $2 \%$ NHS, $0.1 \%$ Triton X-100) at $4^{\circ} \mathrm{C}$. After being rinsed thoroughly in PBS, the tissue was incubated in biotinylated horse antimouse IgG antibody (1:150; in PBS, $0.1 \%$ NHS, $0.1 \%$ Triton X-100; Vector Laboratories) for $2 \mathrm{hr}$, followed by avidin-biotin-horseradish peroxidase complex (Vector Laboratories) for $90 \mathrm{~min}$. Specimens were reacted with $\mathrm{DAB}$ for $6 \mathrm{~min}$ and mounted on microscope slides in glycerol/PBS

Transmission electron microscopy. To assess morphological changes in hair cells qualitatively, we fixed the utricles in $2.5 \%$ glutaraldehyde and $2 \%$ paraformaldehyde overnight at $4^{\circ} \mathrm{C}$. Tissue was post-fixed for $1 \mathrm{hr}$ in osmium tetroxide, stained en bloc with $1 \%$ uranyl acetate for $1 \mathrm{hr}$, serially dehydrated through an acetone series, and embedded in Epon Araldite. Ultrathin sections were poststained with $1 \%$ uranyl acetate and lead citrate. The specimens were imaged with a Philips EM-300 transmission electron microscope.

\section{Data analysis}

All counts of labeled cells were conducted "blind" with respect to pharmacological treatment.

Counts of calretinin-labeled cells. Whole-mount preparations were visualized on a Zeiss Axiovert 135 microscope, and video images of microscopic fields were displayed on a Sony monitor via a Cohu CCD camera. Cell counts were made directly from the video monitor by using calibrated templates that outlined fields of $100 \times 100 \mu \mathrm{m}$. Selected regions from either the striolar or extrastriolar regions of the utricle were displayed on the video monitor. Calretinin-labeled cells were counted from six regions in the central extrastriolar region and four regions distributed along the striolar region of each utricle. Care was taken to avoid the lateral limits of the sensory epithelium because these regions frequently contained areas of epithelial damage resulting from the surgical dissection. The regions were averaged to obtain an estimate of the number of surviving hair cells $/ 10,000 \mu \mathrm{m}^{2}$ for the striolar or extrastriolar region of each specimen.

Counts of fluorescent nucleic acid staining. Bisbenzimide-labeled cells were counted in whole-mount preparations of the utricular maculae by using fluorescent optics with a DAPI filter (excitation, $346 \mathrm{~nm}$; emission, $460 \mathrm{~nm}$ ). Each pyknotic nucleus in eight randomly selected regions of each utricular macula was counted, using a reticule and a $40 \times$ objective, and then normalized to $25,000 \mu \mathrm{m}^{2}$. Pyknotic nuclei were detected easily 
by their condensed chromatin. The number of pyknotic cells per 25,000 $\mu \mathrm{m}^{2}$ of sensory epithelium was calculated for each explant.

Counts of TUNEL-labeled cells. Each TUNEL-labeled cell in six extrastriolar regions of each utricular macula was counted, using a reticule and a $60 \times$ objective. The number of TUNEL-labeled cells per $25,000 \mu \mathrm{m}^{2}$ of sensory epithelium was calculated for each explant. Again, care was taken to avoid the lateral limits of the sensory epithelium to avoid counting cells damaged by the surgical dissection. Such regions were distinguished by the obvious discontinuities in the apical surface of the sensory epithelium and large numbers of labeled cells in and immediately surrounding the regions of damage.

Counts of BrdU-labeled cells in whole mounts. BrdU-labeled epithelial cells in whole-mount preparations of the utricular maculae were counted by light microscopy. Each BrdU-labeled cell was counted from six randomly selected regions of the extrastriolar region of each utricular macula, using a reticule and a $60 \times$ objective. The number of BrdUlabeled sensory epithelial cells per $25,000 \mu \mathrm{m}^{2}$ of sensory epithelia was calculated for each explant.

Counts of BrdU-labeled cells in epithelial cultures. Quantification of cell proliferation in the epithelial cultures was performed directly from the video monitor by using calibrated templates that outlined fields of $100 \times$ $100 \mu \mathrm{m}$. Previous studies have shown that the proliferation of supporting cells in epithelial cultures depends on local cell density (Warchol, 1998). To control for this effect, we performed all quantification from confluent regions of the cultures with a cell density of $20-40$ cells $/ 10,000 \mu \mathrm{m}^{2}$. A proliferation index (BrdU-labeled cells/total cells) was computed for each sampled region. Proliferation indices were obtained from four to seven regions within each individual culture.

\section{Statistical analysis}

Data from hair cell counts, bisbenzimide labeling, and BrdU labeling experiments were subjected to either an unpaired two sample $t$ test assuming unequal variances with Microsoft Excel 98 (Microsoft, Redmond, WA) or a one-way ANOVA with SigmaStat (Jandel Scientific Software, Chicago, IL). Post hoc comparisons, when appropriate, used the Tukey-Kramer or Scheffe's test.

\section{RESULTS}

\section{Morphology of the utricle}

The utricle contains both sensory hair cells and nonsensory supporting cells. Hair cells can be identified by their structural features (cuticular plate, stereocilia, and kinocilium) and the location of their nuclei in the lumenal stratum of the sensory epithelium. Two types of hair cells, designated type I and type II, are present in the avian utricular macula and can be differentiated on the basis of morphology and innervation (Jørgensen, 1989). Type I hair cells are located exclusively in the striolar region of the utricular macula, whereas type II hair cells are found throughout the extrastriolar region and in a narrow region of the striola (Jørgensen, 1989). Antibodies recognizing calretinin selectively label hair cells, but not supporting cells or peripheral epithelial cells, in the avian and mammalian vestibular system (Rogers, 1989; Z heng and Gao, 1997). Labeling was particularly evident in the stereocilia bundles (Fig. 1). If the stereocilia bundle was missing, the apical portion of the remaining hair cell was labeled (data not shown). To determine the baseline density of hair cells in the chick utricle in our culture system, we removed utricles from undamaged animals and cultured them for $48 \mathrm{hr}$ in control medium. Hair cells in both the striolar and extrastriolar regions were quantified and expressed as the mean number of calretininlabeled cells $/ 10,000 \mu \mathrm{m}^{2} \pm \mathrm{SD}$. Calretinin-labeled cells were counted from six regions that were distributed throughout the central extrastriolar portion (cotillus) of each utricle and four regions distributed throughout the striolar region. Greater hair cell densities were observed in the extrastriolar region (105.1 \pm $12.5 ; n=4)$ than in the striolar region $(45.6 \pm 2.2 ; n=4)$.

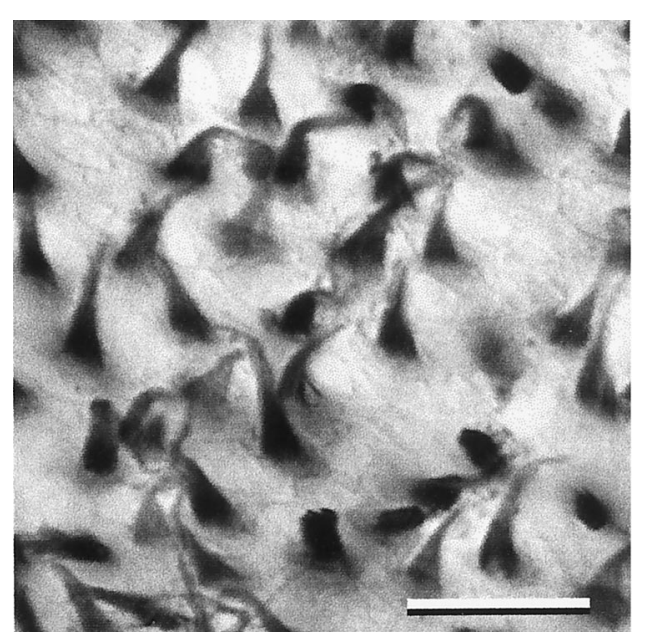

Figure 1. Hair cells labeled for immunoreactivity to calretinin. Utricles from control animals were fixed and processed for immunohistochemistry with the use of an antibody directed against calretinin. Stereocilia bundles and the cuticular plate are labeled. Scale bar, $20 \mu \mathrm{m}$.

\section{Changes in cell survival and nuclear chromatin after neomycin treatment}

Aminoglycoside antibiotics, such as neomycin, selectively kill hair cells in cultures of the avian ear organs (Navaratnam et al., 1996; Stone et al., 1996; Hirose et al., 1997; Kil et al., 1997; Warchol, 1999; Matsui et al., 2000a). To characterize the pattern of hair cell loss induced by neomycin, we incubated utricles in control (aminoglycoside-free) medium for $24 \mathrm{hr}$ and then in $1 \mathrm{~mm}$ neomycin-supplemented medium for another $24 \mathrm{hr}$. Then the utricles were fixed and processed for calretinin immunohistochemistry. Approximately 40 calretinin-positive cells/10,000 $\mu \mathrm{m}^{2}$ were present in the extrastriolar regions of the neomycin-treated specimens, whereas $\sim 18$ hair cells $/ 10,000 \mu \mathrm{m}^{2}$ were found in the striolar regions. This pattern of hair cell loss was similar to that observed in utricles exposed to comparable concentrations of streptomycin sulfate both in vivo (Weisleder and Rubel, 1992, 1993) and in vitro (Matsui et al., 2000a).

To examine changes in the nuclear morphology in hair cells after neomycin treatment, we incubated utricles in $1 \mathrm{~mm}$ neomycin-supplemented medium for $24 \mathrm{hr}$. Fixed specimens were stained with the DNA-binding dye bisbenzimide (Hoechst staining) (Witte et al., 2001). Many cell nuclei in neomycin-treated utricles were intensely stained, branched, and irregularly shaped, indicating massive structural changes in nuclear chromatin (Fig. $2 A)$. In contrast, nuclei of cells in control utricles appeared oval and homogeneously stained with moderate intensity (Fig. 2B). Bisbenzimide-labeled supporting cells could be distinguished from the underlying connective tissue by cell morphology and location within the utricle. Significantly more pyknotic nuclei were found in neomycin-treated cultures when compared with control cultures ( $p<0.001$; Fig. $2 C)$.

\section{Ultrastructural changes after neomycin treatment}

The morphological hallmarks of apoptotic PCD are structural changes such as cell body shrinkage, plasma membrane blebbing, chromatin condensation, and DNA fragmentation (Kerr et al., 1972). The effects of neomycin on the morphology of hair cells were studied using transmission electron microscopy. We sampled approximately eight ultrathin sections per organ from four to five organs per culture condition (total, $\sim 32-40$ sections per condi- 

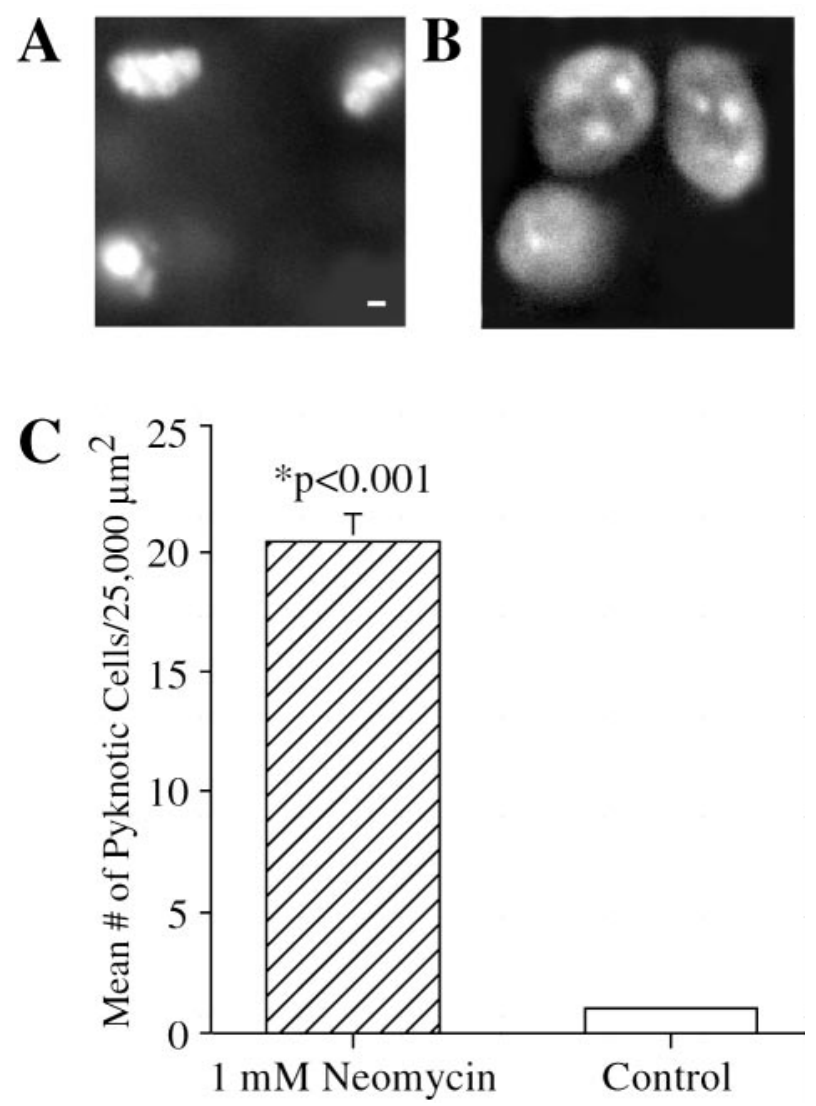

Figure 2. Neomycin induces nuclear chromatin changes in hair cells. Utricles were cultured for $24 \mathrm{hr}$ with $1 \mathrm{~mm}$ neomycin $(A)$ or control medium $(B)$, and then they were fixed and stained with bisbenzimide. Dying cells in neomycin-treated cultures were shaped irregularly and had pyknotic nuclei, whereas cells in control cultures were stained uniformly. Pyknotic cells were quantified in $25,000 \mu \mathrm{m}^{2}$ regions throughout the organ (8 regions per organ; $C$ ). Results are the mean \pm SEM for three experiments from 13 organs. Data point may obscure error bar. Scale bar, $1 \mu \mathrm{m}$.

tion). After exposure to neomycin for $24 \mathrm{hr}$, the hair cell nuclei shrank, nuclear chromatin condensed, and cytoplasm became more electron-dense (Fig. $3 A$ ). There was also a noticeable increase in vacuolization, lipid inclusions, and the formation of intracellular membrane whorls presumably caused by lysosomes (Fig. 3A). Despite these changes, mitochondria were well preserved within the degenerating cell. In control utricle cultures the hair cells appeared normal (Fig. 3B), although some increase in vacuolization was seen when compared with in vivo tissue. There was no evidence of PCD among supporting cells.

\section{Inhibition of protein synthesis promotes hair cell survival}

Apoptosis is an active process in which macromolecules are synthesized to bring about cell death. Previous data indicate that inhibition of protein synthesis prevents death in some types of neurons (Martin et al., 1988; Oppenheim et al., 1990; Scott and Davies, 1990). To determine whether protein synthesis was necessary for aminoglycoside-induced hair cell death, we cultured utricles for $24 \mathrm{hr}$ with neomycin and $1 \mu \mathrm{g} / \mathrm{ml}$ cycloheximide, a macromolecule synthesis inhibitor. This treatment nearly doubled the number of surviving calretinin-positive cells (Fig. 4). Hair cell densities in the extrastriolar region were $72.2 \pm 17.4$ in cycloheximide-/neomycin-treated tissue and $43.5 \pm 8.0$ in neomycin-treated tissue. In the striolar regions the hair cell densities were $37.2 \pm 10.1$ in cycloheximide-/neomycin-treated tissue and $19.2 \pm 3.6$ in neomycin-treated tissue. It appears that hair cell loss was reduced, but not stopped, by cycloheximide treatment.

An additional experiment examined whether cycloheximide was toxic to hair cells. Utricles were cultured without neomycin in the presence or absence of $1 \mu \mathrm{g} / \mathrm{ml}$ cycloheximide for $24 \mathrm{hr}$. Hair cell densities were 88.6 \pm 14.2 in the extrastriolar region of cycloheximide-treated tissue versus $88.3 \pm 14.4$ hair cells in control tissue. In the striolar region the hair cell densities were $51.0 \pm 9.3$ hair cells in cycloheximide-treated tissue and $47.8 \pm$ 9.4 hair cells in control tissue $(n=8$, cycloheximide; $n=9$, controls). There was no significant difference in hair cell density between cycloheximide-treated cultures and control cultures $(p>0.5)$, indicating that short-term exposure to cycloheximide is not toxic to hair cells.

\section{Caspase inhibitors increase hair cell survival after treatment with neomycin}

Caspase induction results in the activation of nucleases and the cleavage of nuclear structural proteins, which can cause cell death. Application of caspase inhibitors can prevent PCD in neurons (Salvesen and Dixit, 1997). In one set of experiments, we investigated whether BAF, a general caspase inhibitor, could reduce the number of pyknotic nuclei in the sensory regions of the utricle after neomycin treatment. Utricles were cultured for $24 \mathrm{hr}$ with $1 \mathrm{~mm}$ neomycin and $50 \mu \mathrm{M}$ BAF or $0.1 \%$ DMSO (vehicle) and then were stained with bisbenzimide. Significantly fewer pyknotic nuclei $(p<0.001)$ were observed in BAF/neomycintreated utricles when compared with neomycin-treated cultures (Fig. 5A).

Caspase activation also can cause DNA strand breaks during PCD, and DNA fragmentation has been observed to occur before pyknosis. Dying cells can be detected by enzymatically labeling the free $3^{\prime}-\mathrm{OH}$ termini of fragmented DNA with modified nucleotides (TUNEL labeling). Utricles were cultured for $24 \mathrm{hr}$ with 1 $\mathrm{mm}$ neomycin and $50 \mu \mathrm{M}$ BAF or $0.1 \%$ DMSO and then were processed for TUNEL labeling (Kil et al., 1997). The number of TUNEL-labeled cells decreased significantly in BAF-treated cultures, relative to controls (Fig. 5B). To control for possible DMSO toxicity to hair cells, we cultured utricles in control medium or $0.1 \%$ DMSO-supplemented medium and found that there was no significant difference $(p=0.3)$ in the number of TUNEL-labeled cells/25,000 $\mu^{2}$ with either medium condition (26.9 \pm 4.7, DMSO; $23.2 \pm 6.2$, controls).

In addition to TUNEL labeling, we assayed hair cell survival by counting calretinin-labeled hair cells. Utricles were cultured for $24 \mathrm{hr}$ with three different concentrations of neomycin $(0.2,0.5$, and $1 \mathrm{mM}$ ) and either $50 \mu \mathrm{M}$ BAF or $0.1 \%$ DMSO. Approximately $40 \%$ more hair cells were present in both the extrastriolar and the striolar regions of BAF-treated utricles than in controls (Figs. 6, $7 A$, Table 1).

To determine whether BAF treatment resulted in the longterm survival of hair cells or simply delayed their death, we cultured utricles for $1 \mathrm{~d}$ in $1 \mathrm{~mm}$ neomycin and $50 \mu \mathrm{M}$ BAF or $0.1 \%$ DMSO. Then the cultures were washed thoroughly and maintained in vitro for an additional $5 \mathrm{~d}$ in control medium (total 7 DIV) and processed for calretinin immunohistochemistry. After 7 DIV, many cultured utricles had curled up, and the striolar region was difficult to quantify, so only the extrastriolar region was analyzed. After 7 DIV, there were similar hair cell densities 

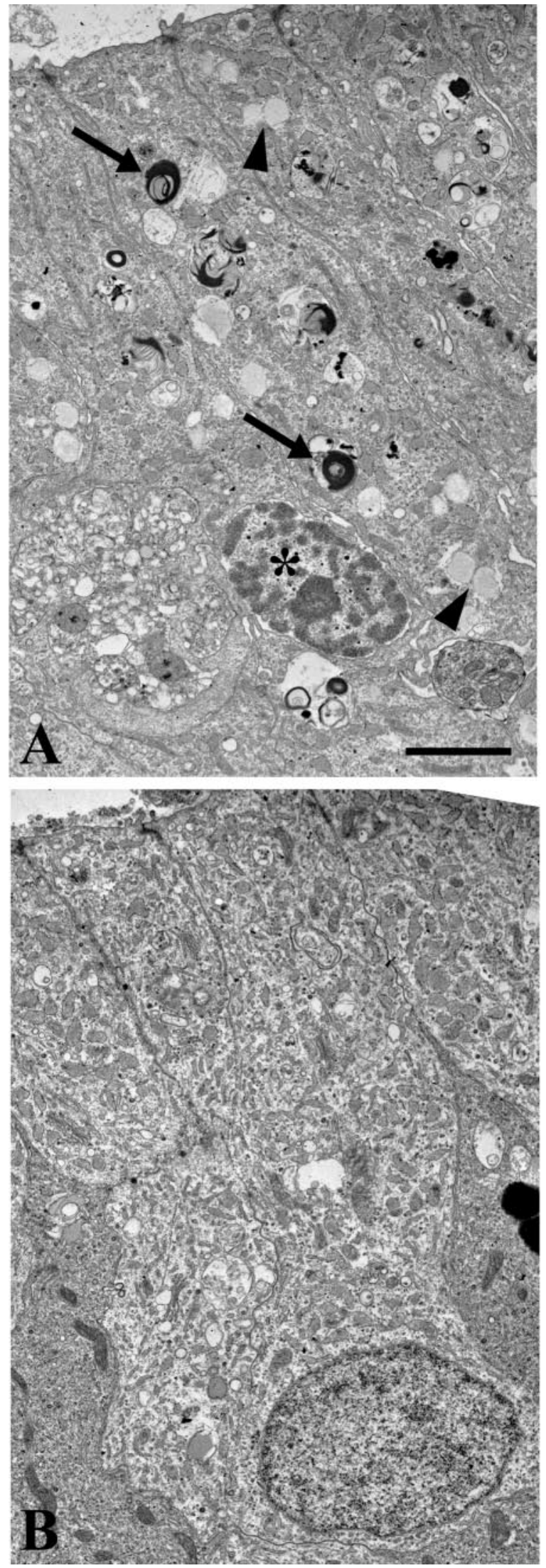

Figure 3. Ultrastructural changes in hair cells after $24 \mathrm{hr}$ of neomycin treatment. Shown are transmission electron microscopy micrographs of hair cells from utricles cultured in $1 \mathrm{~mm}$ neomycin $(A)$ or control medium $(B)$. Hair cells in neomycin-treated cultures had condensed and frag-

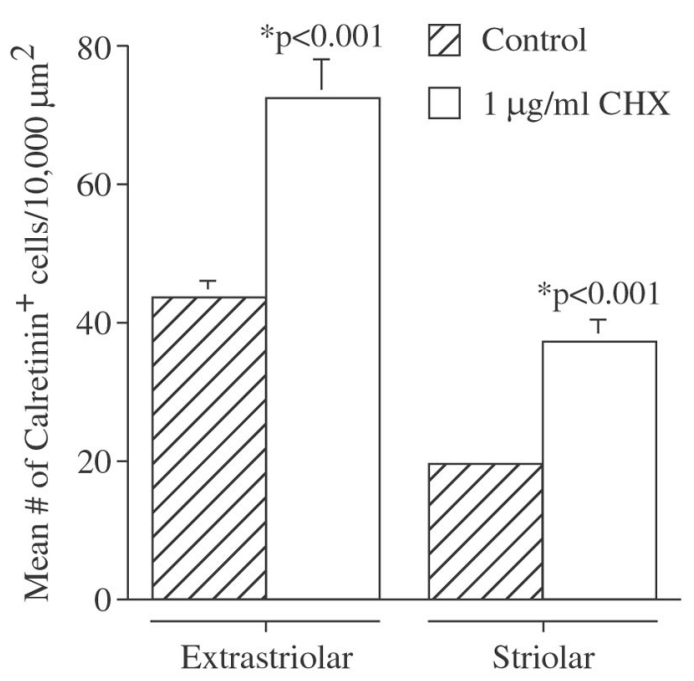

Figure 4. Inhibition of macromolecule synthesis promotes hair cell survival in the presence of neomycin. Utricles were cultured for $24 \mathrm{hr}$ with 1 $\mathrm{mm}$ neomycin and $1 \mu \mathrm{g} / \mathrm{ml}$ cycloheximide or control medium. Calretininlabeled cells were quantified in $10,000 \mu \mathrm{m}^{2}$ regions of both the extrastriolar (6 regions per organ) and striolar (4 regions per organ) areas Results are the mean \pm SEM for three experiments from 10-12 organs. Data point may obscure the error bar.
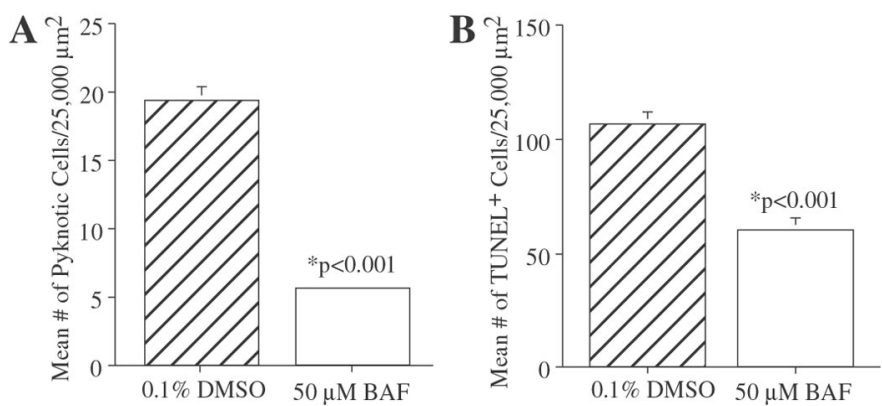

Figure 5. Caspase inhibitors prevent hair cell death after neomycin treatment. Utricles were cultured for $24 \mathrm{hr}$ with $1 \mathrm{~mm}$ neomycin and $0.1 \%$ DMSO (carrier) or $50 \mu \mathrm{M}$ BAF. Cultures were fixed, and the nuclei were stained with Hoechst $(A)$ or were processed for TUNEL labeling $(B)$. Pyknotic cells were quantified in $25,000 \mu \mathrm{m}^{2}$ regions throughout the organ ( 8 regions per organ). $\mathrm{TUNEL}^{+}$cells were quantified in 25,000 $\mu \mathrm{m}^{2}$ regions throughout the organ (6 regions per organ). Results are the mean \pm SEM for three experiments from $10-13$ organs. Data point may obscure the error bar.

in utricles that were treated with BAF and neomycin and control cultures. Hair cell density in BAF-/neomycin-treated cultures was $85.9 \pm 3.6$ versus $46.1 \pm 5.6$ in neomycin-treated cultures or $88.7 \pm 2.7$ in control cultures that were treated with $0.1 \%$ DMSO (Fig. $7 B$ ). This indicates that hair cells saved by BAF can survive for at least $5 \mathrm{~d}$.

Finally, we tested a different caspase inhibitor to determine whether it promotes hair cell survival. Utricles were cultured with $1 \mathrm{~mm}$ neomycin and $25 \mu \mathrm{M} \mathrm{zVAD}$ or $0.1 \%$ DMSO, fixed, and immunoreacted to detect calretinin. The addition of zVAD to the

$\leftarrow$

mented nuclear chromatin $(*)$. Vacuoles, intracellular membrane whorls (arrows), and lipid inclusions (arrowheads) were observed also. In control cultures, the hair cells appeared normal, with no significant morphological changes. Mitochondria were intact in both control and degenerating cells. Scale bar, $2 \mu \mathrm{m}$. 

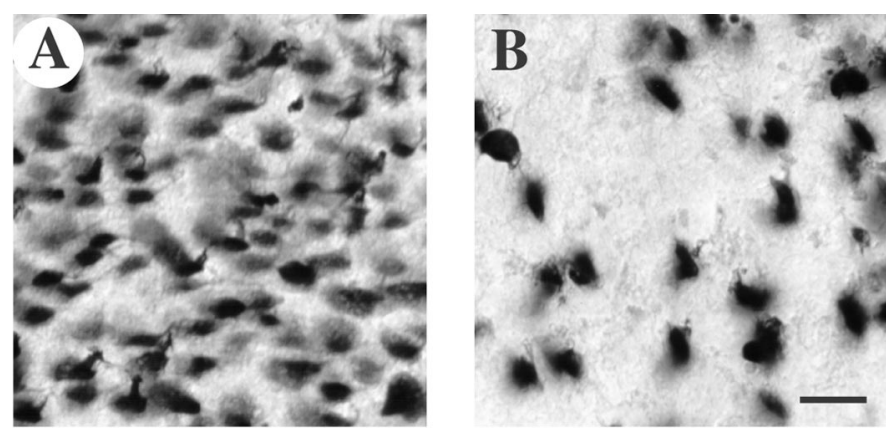

Figure 6. Photomicrograph of hair cells that were treated with neomycin and with or without BAF. Utricles were cultured for $24 \mathrm{hr}$ in $1 \mathrm{~mm}$ neomycin and $0.1 \%$ DMSO $(A, B)$ and $50 \mu \mathrm{M} \operatorname{BAF}(A)$. Enhanced numbers of hair cells were present in BAF-treated cultures compared with cultures that contained neomycin alone. Scale bar, $10 \mu \mathrm{m}$.

cultures had a protective effect comparable with that of BAF (Fig. 7C).

\section{Ongoing cell death occurs in cultured utricles}

Hair cells in the mature avian vestibular system die spontaneously and are replaced continuously (Jørgensen and Mathiesen, 1988; Roberson et al., 1992; Kil et al., 1997; Wilkins et al., 1999). To characterize the amount of ongoing cell apoptosis in vestibular organs, we cultured utricles in control medium for $24 \mathrm{hr}$ and then processed them for TUNEL labeling. Specimens contained $15.3 \pm 1.4$ TUNEL-labeled cells/25,000 $\mu \mathrm{m}^{2}$. TUNEL-labeled cells were randomly distributed throughout the sensory epithelia. Both the number and the density of the TUNEL-labeled cells were in agreement with the data of Kil et al. (1997).

In light of this observation, we wished to determine whether ongoing hair cell death in utricles resulted from the activation of caspases. Specimens were incubated for $24 \mathrm{hr}$ in medium supplemented with 10,50 , or $100 \mu \mathrm{M}$ BAF or $0.1 \%$ DMSO. Significantly fewer TUNEL-labeled cells were observed in $50 \mu \mathrm{M}$ BAF-treated organs when compared with DMSO-treated organs $(p<0.001$; Fig. 8A). Ongoing apoptosis was reduced by $\sim 50 \%$ in $50 \mu \mathrm{M}$ BAF-treated cultures and by $\sim 80 \%$ in $100 \mu \mathrm{M}$ BAF-treated cultures.

\section{Preventing ongoing cell death reduces supporting cell proliferation}

It has been hypothesized that the death of hair cells triggers the proliferation of nearby supporting cells (Corwin and Cotanche, 1988; Girod et al., 1989; Raphael and Altschuler, 1992; Roberson et al., 1992; Hashino and Salvi, 1993; Stone and Cotanche, 1994; Warchol and Corwin, 1996). To investigate the relationship between ongoing cell death and the level of supporting cell proliferation in the chick vestibular organs, we inhibited hair cell death by treatment with BAF. Proliferating cells were labeled by the addition of BrdU to the medium for the final $4 \mathrm{hr}$ in vitro. Significantly fewer BrdU-labeled cells were observed in cultures that were treated with $50 \mu \mathrm{M}$ BAF compared with control cultures $(p<0.001$; Fig. $8 B$ ). In fact, supporting cell proliferation decreased by $>50 \%$ in $50 \mu \mathrm{M}$ BAF-treated cultures and by nearly $90 \%$ in $100 \mu \mathrm{M}$ BAF-treated cultures. This result suggests that reducing hair cell death causes a reduction in supporting cell proliferation. It was important, however, to demonstrate that BAF and zVAD did not inhibit cell proliferation directly. To address this issue, we studied the effects of caspase inhibitors on supporting cell proliferation in cultures of isolated pieces of utricular sensory epithelium maintained on fibronectin substrates. Isolated sheets of utricular sensory epithelia were cultured for 48 $\mathrm{hr}$ in medium supplemented with $50 \mu \mathrm{M}$ BAF, $25 \mu \mathrm{M}$ zVAD, or $0.1 \%$ DMSO (controls). In addition, BrdU was added to the medium for the final $4 \mathrm{hr}$ in vitro. After fixation and processing for BrdU immunohistochemistry, the numbers of BrdU-labeled cells were quantified from confluent regions with cell densities of 20-40 cells $/ 10,000 \mu \mathrm{m}^{2}$, using methods described by Warchol (1999). A proliferation index, defined as the number of BrdUlabeled cells/total number of cells per $10,000 \mu \mathrm{m}^{2}$, was calculated for each sampled region. Similar levels of supporting cell proliferation were observed in control, BAF-treated, and zVADtreated cultures. The proliferation index was $0.20 \pm 0.03$ in control cultures, $0.20 \pm 0.01$ in BAF-treated cultures (Fig. 8C), and $0.23 \pm 0.01(p=0.9)$ in zVAD-treated cultures. These results indicate that treatment with caspase inhibitors does not directly inhibit the proliferation of vestibular supporting cells.

In a separate series of experiments, we treated utricles with 25 $\mu \mathrm{M}$ aphidicolin, which prevents DNA synthesis after entry into S phase for $24 \mathrm{hr}$, and then we processed the tissue for TUNEL labeling. Treatment with aphidicolin had no effect on ongoing apoptosis. Dying cell densities were $4.9 \pm 1.3$ in aphidicolintreated cultures versus $3.4 \pm 0.7$ in control cultures $(p=0.8 ; n=$ $8-9)$. Parallel experiments with BrdU showed that aphidicolin inhibited supporting cell proliferation to $7 \%$ of control values. Taken together, these results indicate that blocking supporting cell proliferation is not sufficient to induce hair cell death.

\section{DISCUSSION}

Results presented here demonstrate that hair cells exposed to neomycin exhibit classically defined apoptotic morphologies, as assessed by light microscopy and transmission electron microscopy. Additionally, the death of neomycin-treated hair cells requires de novo protein synthesis. Caspase activation is required for both ongoing- and neomycin-induced hair cell death. Finally, our results suggest a causative relationship between ongoing (spontaneous) hair cell death and supporting cell proliferation.

\section{Aminoglycosides kill vestibular hair cells in vitro}

Previous work has shown that neomycin kills hair cells in organ cultures of inner ear sensory organs (Richardson and Russell, 1991; Warchol et al., 1993; Saffer et al., 1996; Kil et al., 1997; Quint et al., 1998). In the present study, treatment with neomycin resulted in increased numbers of pyknotic and condensed nuclei and enhanced TUNEL labeling. In addition, observations with transmission electron microscopy revealed morphological changes characteristic of apoptosis, including condensed, marginated, and fragmented nuclei and intact mitochondria (Wyllie et al., 1980). These observations are consistent with previous studies of the effects of aminoglycosides on hair cells in mammals (Forge, 1985; Kotecha and Richardson, 1994; Li et al., 1995; Forge and Li, 2000).

Treatment with three different pharmacological agents (cycloheximide, BAF, and zVAD) increased hair cell survival by $40-$ $50 \%$ after exposure to $1 \mathrm{~mm}$ neomycin. Significantly, none of these agents completely prevented hair cell death. Rather, a substantial number of hair cells died regardless of the deathblocking pharmacological agent that was used. One plausible explanation for this observation is that exposure to $1 \mathrm{~mm}$ neomycin for $24 \mathrm{hr}$ causes some chick vestibular hair cells to die via necrosis. Although no necrotic hair cells were observed in a recent study of the effects of aminoglycosides on cultured mam- 
Table 1. Protective effects of BAF on hair cell death induced by neomycin in vitro

\begin{tabular}{|c|c|c|c|c|c|c|}
\hline & \multicolumn{2}{|c|}{$0.2 \mathrm{~mm}$ Neomycin } & \multicolumn{2}{|c|}{$0.5 \mathrm{~mm}$ Neomycin } & \multicolumn{2}{|c|}{$1 \mathrm{~mm}$ Neomycin } \\
\hline & $0.1 \%$ DMSO & $50 \mu \mathrm{M}$ BAF & $0.1 \%$ DMSO & $50 \mu \mathrm{M}$ BAF & $0.1 \%$ DMSO & $50 \mu \mathrm{M}$ BAF \\
\hline Extrastriolar & $68.5 \pm 2.8$ & $101.2 \pm 4.6$ & $60.2 \pm 4.1$ & $94.7 \pm 5.1$ & $50.9 \pm 3.4$ & $89.2 \pm 4.0$ \\
\hline Striolar & $40.0 \pm 1.4$ & $59.5 \pm 2.4$ & $23.5 \pm 2.4$ & $38.4 \pm 2.8$ & $18.5 \pm 1.3$ & $31.3 \pm 1.8$ \\
\hline
\end{tabular}

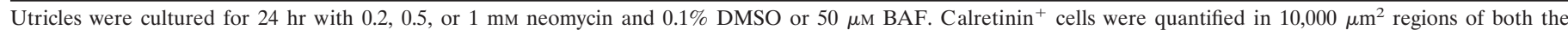
extrastriolar (six regions/organ) and striolar (four regions/organ) areas. Results are the mean \pm SEM for three experiments from $10-13$ organs.

malian vestibular organs (Forge and Li, 2000), another study reported some necrotic hair cells in control cultures after prolonged incubation ( $\mathrm{Li}$ and Forge, 1995). Alternatively, a caspase-independent pathway could mediate some hair cell death. In cerebellar granule cells, general caspase inhibitors have only a marginal survival-promoting effect, suggesting the presence of a caspase-independent death pathway (Miller et al., 1997). Multiple cell death pathways also have been demonstrated in sympathetic neurons (Deshmukh and Johnson, 2000). In that study, treatment with staurosporine resulted in two distinct forms of neuronal death, depending on the concentration of staurosporine (Deshmukh and Johnson, 2000). Low concentrations of staurosporine induced degeneration that resembled the apoptotic death induced by nerve growth factor deprivation. In contrast, treatment with high concentrations resulted in a caspase-independent form of death, with chromatin changes that were neither TUNEL-positive nor necrotic. These results illustrate the need to assess cell death by multiple criteria; further studies are needed to identify more components of the aminoglycoside-induced death pathway in hair cells.

Hair cell densities in all cultured utricles were lower than the values obtained from utricles in vivo (Warchol, 2001), indicating that some death occurs even in the control cultures. Spontaneous death of mature hair cells in cultures of inner ear sensory organs has been reported in previous studies (Oesterle et al., 1993; Stone et al., 1996; Quint et al., 1998; Matsui et al., 2000a). In addition, avian vestibular hair cells have a relatively short lifespan (Kil et al., 1997; Goodyear et al., 1999; Stone et al., 1999; Wilkins et al., 1999), and this could be a causative agent for the density differences. Alternatively, the sensory epithelia could expand after placement in culture. Such expansion also would result in decreased hair cell density.

\section{General caspase inhibitors promote hair cell survival}

Apoptosis is mediated by proteases of the caspase family (Salvesen and Dixit, 1997). In the present study, the general caspase inhibitor BAF promoted hair cell survival when used in conjunction with three different neomycin concentrations. At best, no more than $50 \%$ of the original hair cell population was rescued by either BAF or $\mathrm{ZVAD}$. This is comparable with the protective effect of BAF in other sensory organs when maintained in culture (Ogilvie, 2001). In contrast, a similar study of mature mammalian utricles found that BAF treatment saved nearly all hair cells after $1 \mathrm{~mm}$ gentamycin treatment (Forge and Li, 2000). Different culture conditions, different aminoglycosides, and species differences could account for the discrepancy in hair cell survival. For example, chick vestibular hair cells have been estimated to live from $\sim 1$ to 15 weeks, whereas mammalian vestibular hair cells are capable of surviving for the entire lifetime of the animal (Roberson et al., 1992; Rubel et al., 1995; Kil et al., 1997; Goodyear et al., 1999; Stone et al., 1999; Wilkins et al., 1999). These observations suggest that the cell death pathway(s) in the avian vestibular organs may show some important differences from their mammalian counterparts.

\section{Relationship between spontaneous hair cell death and ongoing cell addition}

Several previous studies have demonstrated ongoing cell proliferation in mature vestibular organs (Jørgensen and Mathiesen, 1988; Roberson et al., 1992; Warchol and Corwin, 1993; Weisleder and Rubel, 1993; Rubel et al., 1995; Kil et al., 1997; Wilkins et al., 1999) and have demonstrated that the baseline level of proliferation appears to be counterbalanced by ongoing hair cell death (Kil et al., 1997; Goodyear et al., 1999; Stone et al., 1999; Wilkins et al., 1999). This dynamic pattern of ongoing cell death and proliferation differs from that observed in the chicken cochlea, in which the supporting cells are mitotically quiescent until the hair cells are lost because of trauma (Corwin and Cotanche, 1988; Oesterle and Rubel, 1993) or proliferate at a very low rate (Oesterle and Rubel, 1993). The results of these previous studies, however, leave the relationship between ongoing cell death and cell proliferation unclear. The loss of vestibular hair cells may stimulate supporting cell proliferation, but spontaneous supporting cell proliferation might also trigger the death of hair cells. In the present study, we examined the effects of caspase inhibition on spontaneous hair cell death in the chick utricle and showed that caspase inhibitors reduced the amount of ongoing hair cell death by $\sim 50-85 \%$. Significantly, caspase inhibition also reduced ongoing supporting cell proliferation to $\sim 50-90 \%$ of control levels. Data obtained from isolated sensory epithelia indicate that caspase inhibitors do not directly affect supporting cell proliferation, which is consistent with previous data from a variety of mammalian cell types (Jacobsen et al., 1996). Taken together, these results suggest that ongoing hair cell death stimulates supporting cell proliferation in the mature utricle.

\section{Receptor turnover in other sensory systems}

The stimulus that causes hair cells to die spontaneously is not known. Ongoing turnover of sensory receptors has been demonstrated in other sensory systems. In the olfactory sensory epithelium new neurons continually replace olfactory receptor neurons that have been lost by apoptosis (Holcomb et al., 1995). A recent study has indicated that cells die in the olfactory sensory epithelium, via a ligand-mediated cell death pathway (e.g., fas and fas-ligand; Farbman et al., 1999). Another study has implicated the $\mathrm{Bcl}-2$ protein in neuronal turnover under basal conditions (Hayward and Morgan, 1995). Mature olfactory receptor neurons normally live at least $90 \mathrm{~d}$, but when mice are reared in a laminar flow hood to prevent rhinitis, olfactory receptor neurons can survive as long as 12 months (Hinds et al., 1984). Therefore, the turnover of olfactory receptor neurons may be regulated by environmental factors. Actively dying olfactory receptor neurons could provide a positive signal that stimulates neuronal precursor proliferation. Alternatively, differentiated neurons may produce 

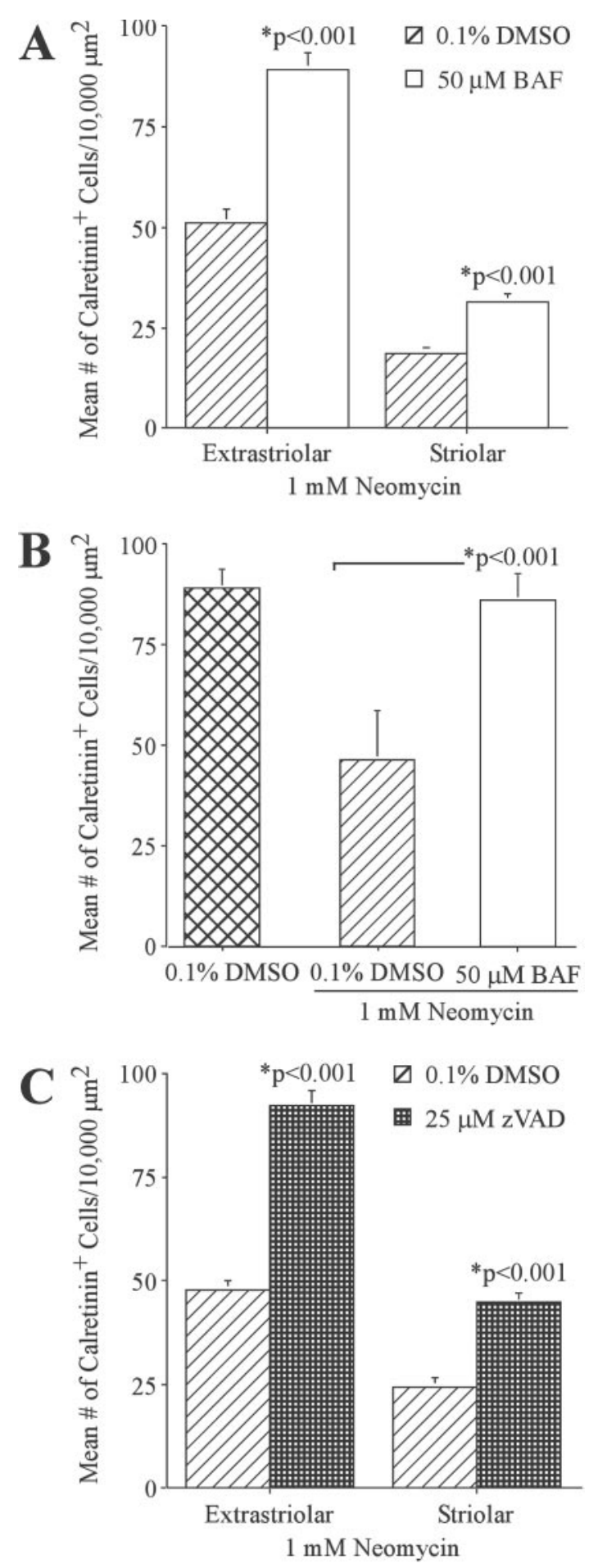

Figure 7. Caspase inhibitors promote hair cell survival after neomycin treatment. In short-term experiments the utricles were cultured for $24 \mathrm{hr}$ with $1 \mathrm{~mm}$ neomycin and $0.1 \% \operatorname{DMSO}(A, C), 50 \mu \mathrm{M}$ BAF $(A)$, or $25 \mu \mathrm{M}$ zVAD $(C)$. In long-term experiments $(B)$ the utricles were cultured for 24 hr with $0.1 \%$ DMSO, 1 mM neomycin, or $1 \mathrm{~mm}$ neomycin and $50 \mu \mathrm{M} \mathrm{BAF}$; they were washed and then cultured for $5 \mathrm{~d}$ in control medium. Calretinin $^{+}$cells were quantified in $10,000 \mu \mathrm{m}^{2}$ regions of both the extrastriolar (6 regions per organ) and striolar (4 regions per organ) areas. In the long-term cultures the calretinin ${ }^{+}$cells were quantified in the extrastriolar region only. Similar levels of hair cell survival were observed in BAF/neomycin-treated cultures and control cultures after 5 DIV. Results are the mean \pm SEM for three experiments from 10-13 organs.
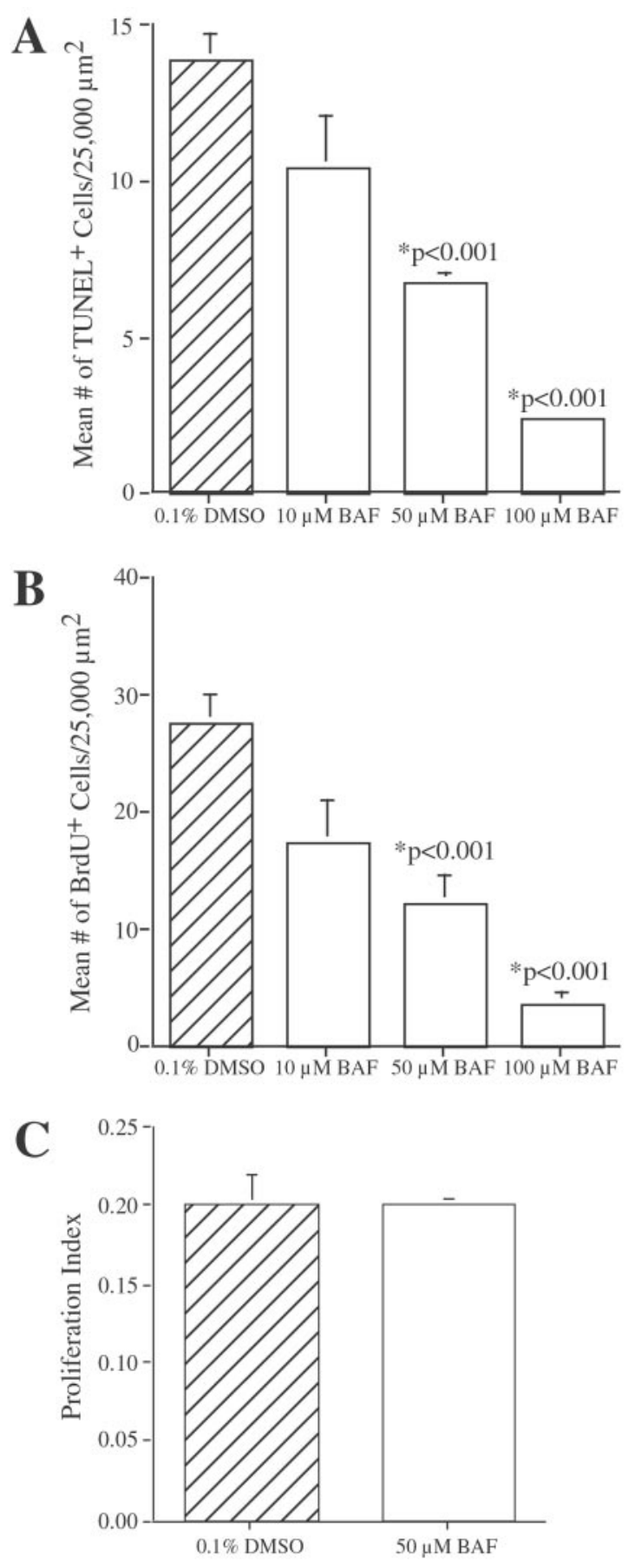

Figure 8. BAF reduces ongoing cell death in the avian inner ear. Utricles $(A, B)$ or isolated sensory epithelia $(C)$ were cultured for $24 \mathrm{hr}$ with $0.1 \%$ DMSO (controls) or 10, 50, or $100 \mu \mathrm{M}$ BAF. Fixed specimens then were processed for TUNEL labeling $(A)$ or BrdU immunohistochemistry $(B$, $C)$. $\mathrm{TUNEL}^{+}$or $\mathrm{BrdU}^{+}$cells were quantified in the extrastriolar regions in each organ and then were normalized to $25,000 \mu \mathrm{m}^{2}$. Results are the mean \pm SEM for three experiments from seven to nine organs. Significantly fewer TUNEL ${ }^{+}$cells were present in BAF-treated specimens $(A)$. In addition, correspondingly fewer $\mathrm{BrdU}^{+}$cells were present in BAFtreated cultures compared with controls $(B)$. $C$, Plot of proliferation index $\left(\mathrm{BrdU}^{+}\right.$cells/total cells) in a $10,000 \mu \mathrm{m}^{2}$ region, demonstrating that BAF does not affect supporting cell proliferation directly. Combined results from these experiments suggest a causative relationship between ongoing hair cell death and ongoing supporting cell proliferation. 
an inhibitory signal that prevents progenitor cells from dividing and generating new neurons as long as the normal compliment of neurons is intact. Several studies support the former hypothesis by demonstrating an increase in progenitor cell proliferation after injury (for review, see Murray and Calof, 1999). No studies, however, have been able to rule out the latter mechanism completely.

Gustatory receptors also have a limited lifespan and must be replaced to maintain the structure of the sensory epithelium. In rodents, the sensory cells in taste buds are replaced every 9-14 d (Beidler and Smallman, 1965; Farbman, 1980; Delay et al., 1986; Zeng and Oakley, 1999). Because each taste bud contains $\sim 50-75$ cells, this turnover rate implies that approximately three to five cells are replaced each day. This estimate corresponds to the number of apoptotic cells that are observed under normal conditions in lingual taste buds (Takeda et al., 1996). A recent study suggested that gustatory cells die via a p53/Bax-dependent cell death pathway (Zeng and Oakley, 1999), but the precise signals that trigger the programmed death of cells in the adult gustatory sensory epithelium are not known.

Turnover of sensory receptors also has been demonstrated in certain hair cell epithelia. For instance, hair cell death has been reported in lateral line organs of various fish (Jørgensen, 1991), and a recent report has indicated that hair cells in the postembryonic zebrafish lateral line also turn over naturally (Williams and Holder, 2000). Significantly, those authors also noted that zebrafish neuromasts that were treated with zVAD displayed decreased hair cell death and decreased ongoing supporting cell division. No mechanism has been proposed as the hair cell death stimulus, but environmental stressors may cause the turnover of lateral line hair cells because they are situated on the animal's external surface and are exposed to water constantly.

\section{Summary}

The results of the present study, in agreement with previous data, demonstrate that cultured hair cells undergo apoptosis after exposure to aminoglycosides (Li et al., 1995; Forge and Li, 2000) and that aminoglycoside-induced hair cell death can be reduced by the inhibition of caspases and protein synthesis. It is not clear, however, whether caspase inhibitors also promote hair cell survival in vivo and whether the surviving hair cells are functional. Additional studies should also elucidate other aspects of the aminoglycoside-induced cell death pathway. Because caspases are used to mediate cell death, identifying which caspases are necessary for hair cell death may determine whether there is a single cell death pathway or whether there are multiple parallel cell death pathways.

\section{REFERENCES}

Beidler LM, Smallman RL (1965) Renewal of cells within taste buds. J Cell Biol 27:263-272.

Corwin JT, Cotanche DA (1988) Regeneration of sensory hair cells after acoustic trauma. Science 240:1772-1774.

Delay RJ, Kinnamon JC, Roper SD (1986) Ultrastructure of mouse vallate taste buds. II. Cell types and cell lineage. J Comp Neurol 253:242-252.

Deshmukh M, Johnson Jr EM (2000) Staurosporine-induced neuronal death: multiple mechanisms and methodological implications. Cell Death Differ 7:250-261.

Farbman AI (1980) Renewal of taste bud cells in rat circumvallate papillae. Cell Tissue Kinet 13:349-357.

Farbman AI, Buchholz JA, Suzuki Y, Coines A, Speert D (1999) A molecular basis of cell death in olfactory epithelium. J Comp Neurol 414:306-314

Forge A (1985) Outer hair cell loss and supporting cell expansion following chronic gentamycin treatment. Hear Res 19:171-182.
Forge A, Li L (2000) Apoptotic death of hair cells in mammalian vestibular sensory epithelia. Hear Res 139:97-115.

Girod DA, Duckert LG, Rubel EW (1989) Possible precursors of regenerated hair cells in the avian cochlea following acoustic trauma. Hear Res 42:175-194.

Goodyear RJ, Gates R, Lukashkin AN, Richardson GP (1999) Hair-cell numbers continue to increase in the utricular macula of the early posthatch chick. J Neurocytol 28:851-861.

Hashino E, Salvi RJ (1993) Changing spatial patterns of DNA replication in the noise-damaged chick cochlea. J Cell Sci 105:23-31.

Hayward MD, Morgan JI (1995) The olfactory system as a model for the analysis of the contribution of gene expression to programmed cell death. Chem Senses 20:261-269.

Hinds JW, Hinds PL, McNelly NA (1984) An autoradiographic study of the mouse olfactory epithelium: evidence for long-lived receptors. Anat Rec 210:375-383

Hirose K, Hockenbery DM, Rubel EW (1997) Reactive oxygen species in chick hair cells after gentamycin exposure in vitro. Hear Res 104:1-14.

Holcomb JD, Mumm JS, Calof AL (1995) Apoptosis in the neuronal lineage of the mouse olfactory epithelium: regulation in vivo and in vitro. Dev Biol 172:307-323.

Jacobsen MD, Weil M, Raff MC (1996) Role of ced-3/ICE-family proteases in staurosporine-induced programmed cell death. J Cell Biol 133:1041-1051.

Jokay I, Soos G, Repassy G, Dezso B (1998) Apoptosis in the human inner ear. Detection by in situ end labeling of fragmented DNA and correlation with other markers. Hear Res 117:131-139.

Jørgensen JM (1981) On a possible hair cell turn-over in the inner ear of the caecilian Ichthyophis glutinosus. Acta Zool 62:171-186.

Jørgensen JM (1989) Number and distribution of hair cells in the utricular macula of some avian species. J Morphol 201:187-204.

Jørgensen JM (1991) Regeneration of lateral line and inner ear vestibular cells. Ciba Found Symp 160:151-163.

Jørgensen JM, Mathiesen C (1988) The avian inner ear. Continuous production of hair cells in vestibular sensory organs, but not in the auditory papilla. Naturwissenschaften 75:319-320.

Kerr JF, Wyllie AH, Currie AR (1972) Apoptosis: a basic biological phenomenon with wide-ranging implications in tissue kinetics. $\mathrm{Br} \mathrm{J}$ Cancer 26:239-257.

Kil J, Warchol ME, Corwin JT (1997) Cell death, cell proliferation, and estimates of hair cell life spans in the vestibular organs of chicks. Hear Res 114:117-126.

Kotecha B, Richardson GP (1994) Ototoxicity in vitro: effects of neomycin, gentamicin, dihydrostreptomycin, amikacin, spectinomycin, neamine, spermine and poly-L-lysine. Hear Res 73:173-184.

Lang H, Liu C (1997) Apoptosis and hair cell degeneration in the vestibular sensory epithelia of the guinea pig following a gentamycin insult. Hear Res 111:177-184.

Li L, Forge A (1995) Cultured explants of vestibular sensory epithelia from adult guinea pigs and effects of gentamycin: a model of examination of hair cell loss and epithelial repair mechanism. Aud Neurosci $1: 111-125$.

Li L, Nevill G, Forge A (1995) Two modes of hair cell loss from the vestibular sensory epithelia of the guinea pig inner ear. J Comp Neurol $355: 405-417$.

Liu W, Staecker H, Stupak H, Malgrange B, Lefebvre P, Van De Water TR (1998) Caspase inhibitors prevent cisplatin-induced apoptosis of auditory sensory cells. NeuroReport 9:2609-2614.

Martin DP, Schmidt RE, DiStefano PS, Lowry OH, Carter JG, Johnson Jr EM (1988) Inhibitors of protein synthesis and RNA synthesis prevent neuronal death caused by nerve growth factor deprivation. J Cell Biol 106:829-844

Matsui JI, Oesterle EC, Stone JS, Rubel EW (2000a) Characterization of damage and regeneration in cultured avian utricles. J Assoc Res Otolaryngol 1:46-63.

Matsui JI, Ogilvie JM, Warchol ME (2000b) A causative relationship between ongoing hair cell death and supporting cell proliferation in avian vestibular organs. Soc Neurosci Abstr 26:230.

Miller TM, Moulder KL, Knudson CM, Creedon DJ, Deshmukh M, Korsmeyer SJ, Johnson Jr EM (1997) Bax deletion further orders the cell death pathway in cerebellar granule cells and suggests a caspaseindependent pathway to cell death. J Cell Biol 139:205-217.

Murray RC, Calof AL (1999) Neuronal regeneration: lessons from the olfactory system. Semin Cell Dev Biol 10:421-431.

Nakagawa T, Yamane H, Shibata S, Nakai Y (1997a) Gentamycin ototoxicity induced apoptosis of the vestibular hair cells of guinea pigs. Eur Arch Otorhinolaryngol 254:9-14.

Nakagawa T, Yamane H, Shibata S, Sunami K, Nakai Y (1997b) Cell death caused by the acute effects of aminoglycoside and zinc in the ampullary cristae of guinea pigs. Eur Arch Otorhinolaryngol 254:153-157.

Nakagawa T, Yamane H, Shibata S, Takayama M, Sunami K, Nakai Y (1997c) Two modes of auditory hair cell loss following acoustic overstimulation in the avian inner ear. J Otorhinolaryngol 59:303-310. 
Nakagawa T, Yamane H, Takayama M, Sunami K, Nakai Y (1998a) Apoptosis of guinea pig cochlear hair cells following chronic aminoglycoside treatment. Eur Arch Otorhinolaryngol 255:127-131.

Nakagawa T, Yamane H, Takayama M, Sunami K, Nakai Y (1998b) Cycloheximide blocks the toxic effect of streptomycin in guinea pig vestibular hair cells. Acta Otolaryngol Suppl 538:36-39.

Nakagawa T, Yamane H, Takayama M, Sunami K, Nakai Y (1998c) Dose-dependent response of vestibular hair cells of guinea pigs following streptomycin ototoxiation. Acta Otolaryngol 118:530-533.

Navaratnam DS, Su HS, Scott SP, Oberholtzer JC (1996) Proliferation in the auditory receptor epithelium mediated by a cyclic AMP-dependent signaling pathway. Nat Med 2:1136-1139.

Nishizaki K, Anniko M, Orita Y, Karita K, Masuda Y, Yoshino T (1998) Programmed cell death in the developing epithelium of the mouse inner ear. Acta Otolaryngol 118:96-100.

Oesterle EC, Rubel EW (1993) Postnatal production of supporting cells in the chick cochlea. Hear Res 66:213-224.

Oesterle EC, Tsue TT, Reh TA, Rubel EW (1993) Hair-cell regeneration in organ cultures of the postnatal chicken inner ear. Hear Res 70:85-108.

Ogilvie JM (2001) Photoreceptor rescue in an organotypic model of retinal degeneration. Concepts and challenges in retinal biology: a tribute to John E. Dowling (Kolb H, ed). Amsterdam: Elsevier.

Oppenheim RW, Prevette D, Tytell M, Homma S (1990) Naturally occurring and induced neuronal death in the chick embryo in vivo requires protein and RNA synthesis: evidence for the role of cell death genes. Dev Biol 138:104-113.

Pirvola U, Xing-Qun L, Virkkala J, Saarma M, Murakata C, Camoratto AM, Walton KM, Ylikoski J (2000) Rescue of hearing, auditory hair cells, and neurons by CEP-1347/KT7515, an inhibitor of c-Jun N-terminal kinase activation. J Neurosci 20:43-50.

Quint E, Furness DN, Hackney CM (1998) The effect of explantation and neomycin on hair cells and supporting cells in organotypic cultures of the adult guinea-pig utricle. Hear Res 118:157-167.

Raff M (1998) Cell suicide for beginners. Nature 396:119-122.

Raphael Y, Altschuler RA (1992) Early microfilament reorganization in injured auditory epithelia. Exp Neurol 115:32-36.

Richardson GP, Russell IJ (1991) Cochlear cultures as a model system for studying aminoglycoside-induced ototoxicity. Hear Res 53:293-311.

Roberson DF, Weisleder P, Bohrer PS, Rubel EW (1992) Ongoing production of sensory cells in the vestibular epithelium of the chick. Hear Res 57:166-174.

Rogers JH (1989) Two calcium-binding proteins mark many chick sensory neurons. Neuroscience 31:697-709.

Rubel EW, Dew LA, Roberson DW (1995) Mammalian vestibular hair cell regeneration. Science 267:701-707.

Saffer LD, Gu RD, Corwin JT (1996) An RT-PCR analysis of mRNA for growth factor receptors in damaged and control sensory epithelia of rat utricles. Hear Res 94:14-23.

Salvesen GS, Dixit VM (1997) Caspases: intracellular signaling by proteolysis. Cell 91:443-446.

Scott SA, Davies AM (1990) Inhibition of protein synthesis prevents cell death in sensory and parasympathetic neurons deprived of neurotrophic factor in vitro. J Neurobiol 21:630-638.

Stone JS, Cotanche DA (1994) Identification of the timing of S phase and the patterns of cell proliferation during hair cell regeneration in the chick cochlea. J Comp Neurol 341:50-67.

Stone JS, Leano SG, Baker LP, Rubel EW (1996) Hair cell differentia- tion in chick cochlear epithelium after aminoglycoside toxicity: in vivo and in vitro observations. J Neurosci 16:6157-6174.

Stone JS, Choi YS, Woolley SM, Yamashita H, Rubel EW (1999) Progenitor cell cycling during hair cell regeneration in the vestibular and auditory epithelia of the chick. J Neurocytol 28:863-876.

Takeda M, Suzuki Y, Obara N, Nagai Y (1996) Apoptosis in mouse taste buds after denervation. Cell Tissue Res 286:55-62.

Torchinsky C, Messana EP, Arsura M, Cotanche DA (1999) Regulation of p27Kip1 during gentamycin-mediated hair cell death. J Neurocytol 28:913-924.

Usami S, Takumi Y, Fujita S, Shinkawa H, Hosokawa M (1997) Cell death in the inner ear associated with aging is apoptosis? Brain Res 747:147-150.

Warchol ME (1995) Supporting cells in isolated sensory epithelia of avian utricles proliferate in serum-free culture. NeuroReport 6:981-984.

Warchol ME (1998) Cell density and cytoskeletal proteins regulate the proliferation of inner ear supporting cells. Assoc Res Otolaryngol Abstr 12:622.

Warchol ME (1999) Immune cytokines and dexamethasone influence sensory regeneration in the avian vestibular periphery. J Neurocytol 28:889-900.

Warchol ME (2001) Lectin from Griffonia simplicifolia identifies a subset of vestibular hair cells. J Neurocytol 30:253-264.

Warchol ME, Corwin JT (1993) Supporting cells in avian vestibular organs proliferate in serum-free culture. Hear Res 71:28-36.

Warchol ME, Corwin JT (1996) Regenerative proliferation in organ cultures of the avian cochlea: identification of the initial progenitors and determination of the latency of the proliferative response. J Neurosci 16:5466-5477.

Warchol ME, Lambert PR, Goldstein BJ, Forge A, Corwin JT (1993) Regenerative proliferation in inner ear sensory epithelia from adult guinea pigs and humans. Science 259:1619-1622.

Weisleder P, Rubel EW (1992) Hair cell regeneration in the avian vestibular epithelium. Exp Neurol 115:2-6.

Weisleder P, Rubel EW (1993) Hair cell regeneration after streptomycin toxicity in the avian vestibular epithelium. J Comp Neurol 331:97-110.

Wilkins HR, Presson JC, Popper AN (1999) Proliferation of vertebrate inner ear supporting cells. J Neurobiol 39:527-535.

Williams JA, Holder N (2000) Cell turnover in neuromasts of zebrafish larvae. Hear Res 143:171-181.

Witte MC, Montcouquiol M, Corwin JT (2001) Regeneration in avian hair cell epithelia: identification of intracellular signals required for S-phase entry. Eur J Neurosci 14:829-838.

Wyllie AH, Kerr JF, Currie AR (1980) Cell death: the significance of apoptosis. Int Rev Cytol 68:251-306.

Zheng JL, Gao WQ (1997) Analysis of rat vestibular hair cell development and regeneration using calretinin as an early marker. J Neurosci 17:8270-8282.

Zheng JL, Keller G, Gao WQ (1999) Immunocytochemical and morphological evidence for intracellular self-repair as an important contributor to mammalian hair cell recovery. J Neurosci 19:2161-2170.

Zeng Q, Oakley B (1999) p53 and Bax: putative death factors in taste cell turnover. J Comp Neurol 413:168-180.

Zheng Y, Ikeda K, Nakamura M, Takasaka T (1998) Endonuclease cleavage of DNA in the aged cochlea of Mongolian gerbil. Hear Res 126:11-18. 